\title{
Carnivals in Venice: The Hoaxing of Théophile Gautier
}

Gautier published his poem, 'Variations sur le carnaval de Venise' in the Revue des deux Mondes on $15^{\text {th }}$ April 1849, and reprinted a lightly revised version in his collection Émaux et Camées [Enamels and Cameos] in 1852. No nineteenthcentury French poem has had a more striking influence on English literature. Browning liked it so much he based both 'A Toccata of Galuppi's' and a segment of Fifine at the Fair on the ground plan of Gautier's poem. And eighteen years later, in The Picture of Dorian Gray, Oscar Wilde quotes three and a half stanzas from 'Variations', and has Dorian remark, 'How exquisite they were! [...] The whole of Venice was in those [...] lines.'

The poem's influence continued into the twentieth century. T.S.Eliot's line, 'Trala-la-la-la-la-laire', which appears in the epigraph to his Venetian poem, 'Burbank with a Baedeker: Bleistein with a Cigar', alludes to the opening of Gautier's second section. And finally, Philip Larkin borrowed Gautier's central idea in 'For Sidney Bechet'. Larkin's narrator imagines listening to a great foreign virtuoso play music from his native land, and allows images of a vanished and idealized New Orleans - another carnival city built on water - to form in his mind; like Gautier, Larkin ends his poem with thoughts of love.

Gautier believed his poem was inspired by the set of variations Paganini wrote on the tune, The Carnival of Venice, and he gives the reader the impression that he is responding to a performance by Paganini himself: the first section says how banal the tune had become until Paganini got hold of it; while the next three sections (beginning with the 'Tra la' line, as Gautier's narrator sings along with the melody) describe various visions of Venice conjured up by the magical variations. But Joanna Richardson and Peter Whyte showed long ago that Gautier was in fact prompted to write his poem after hearing performances by two other violinists, and in this article I intend to show that Gautier was actually responding to a different piece by a different composer altogether. Gautier, like many others, was taken in by a now forgotten piece of dishonesty whose 
exposure filled many columns of the French and English press in 1843-4, and whose consequences would rumble on for several decades.

The Carnival of Venice is an old Italian folk tune that first came to prominence in the now lost Singspiel, Der angenehme Betrug oder Der Carnaval von Venedig [The Pleasant Fraud or The Carnival of Venice] written in 1707 by Reinhard Keiser. The tune acquired its name from the Singspiel and the melody became moderately popular in the eighteenth century, although it gained true celebrity at the beginning of the nineteenth when it was used in Louis Milon's ballet, Le Carnaval de Venise, with music by Louis de Persuis and Rudolphe Kreutzer. First performed at the Paris Opéra on $22^{\text {nd }}$ February 1816, the ballet went on to achieve great and immediate success throughout Europe.

Paganini is said to have first encountered the Carnival theme in Venice in 1816 probably as a result of the ballet's popularity - and he went on to write his set of twenty variations and finale on the tune in 1829; for added brilliance, the violinist is required to tune all his strings up a semitone. According to his first biographer, Julius Schottky, Paganini normally prefaced the piece with a Cantabile Spianato [smooth and song-like] which is almost certainly a version of the slow movement of his third violin concerto, premiered the previous year. Paganini died in 1840, and the variations were not published until 1851, while the Cantabile Spianato, although rediscovered in the 1960s, remained unpublished and unperformed until the early 1970s.

Paganini did not play his Variations sur le carnaval de Venise at the initial concert of his first Paris series in March 1831, and a complete list of his subsequent programmes can no longer be reconstructed, but as the series was long and his Variations popular, it's quite likely he performed them. Gautier was in the audience for Paganini's first Paris concert, and it is quite possible he attended others where he could have heard the Variations. Like everyone else, Gautier was dazzled and amazed by what he saw and heard, but there is no reason for thinking that he found his encounter with Paganini creatively fruitful in the immediately ensuing years. The violinist receives only one cursory reference in a 
poem of Gautier's prior to 1849; in addition, Gautier often liked to try out his ideas for poems in letters and newspaper articles, but Paganini receives only a few passing mention in articles before 1843, and his name does not occur in any of the poet's surviving letters written between 1831 and 1843 .

The first hint of Gautier's 'Variations' is not found in a piece of writing about Paganini, but in an article about Milon's ballet which was revived at the Paris Opéra in August 1838. Looking back on it a month later, the poet recalls the popularity the melody had attained more than twenty years before:

Seeing these old things that charmed our fathers, and whose airs - wheezed by barrel organs at every crossroads - soothed our earliest childhood, brings into the heart a soft and melancholy feeling ...

Nearly five years later, in January 1843, Gautier heard Paganini's only important violin pupil, Camillo Sivori, play a set of variations on the theme, and was much struck by their 'originality and whimsy'. When, in April, he reviewed Sivori playing them again, he goes into detail about the images which came before his mind's eye. These were not of his childhood, but of Venice itself:

The old Venetian air which serves as the theme for these wonderful caprices is delicious and worth several cartloads of operas: it's joyful and melancholy at the same time, laughter is close to tears, and when you hear it played by Sivori all kinds of fantastic visions pass before your eyes. You see the white pigeons of St Mark's swimming in the azure sky; gondolas threading their way beneath marble bridges, every passing note envelops you in a veil of black lace, or raises for a moment a velvet mask beneath which you discover an old love from former times. The modulations languidly lull you to sleep like waves, and the reverie would quite take you over if a nasal and quavering phrase, like a burst of laughter from a group of masquers, didn't suddenly wake you up, and return you to normal life, a smile on your lips.

These two articles clearly form the basis of the poem, but a year later Gautier reviewed Sivori playing the Carnival for the third time, and found yet further aspects to enjoy: 'The slightly mocking melancholy of Venice,' he wrote, 'is wonderfully captured in this air, full of moonlight and coloured lanterns, where tears flow freely down black velvet masks.' This report adds two new ideas that 
find their way into the poem - those of mockery and moonlight - which are not present in the earlier articles.

There are, however, good reasons for believing that the composition Gautier heard on all three occasions in the early 1840s, and which he found so charmingly and movingly evocative, was not written by Paganini as Sivori claimed, but by Sivori's main rival, the great Moravian violinist, Heinrich Wilhelm Ernst.

Ernst had entered into extended competition with Paganini in Marseilles in early 1837, and shortly afterwards composed a set of twenty-five Variations Burlesques on the Carnival of Venice, probably taking his theme from Paganini's piece and writing them in a deliberately Paganinian style. He used the same scordatura [retuning] and prefaced the Variations with his A major Nocturne, Op.8, No.1, which he'd already published as a separate piece two years before. He chose not to publish the complete composition, however, preferring to keep such a light piece for his own concert use. In an age before copyright and mechanical recording, and when virtuosi improvised extensively and altered compositions to suit their own whims, the stage was now set for confusion and acrimony, especially when Ernst's composition turned out to be one of the most popular violin pieces of the mid-nineteenth century.

Confusion and acrimony were not long in arriving. In late 1842 or early 1843, a number of friends wrote to Ernst (who was currently on tour in Scandinavia) saying that two of his rivals - Sivori and Theodore Hauman - were performing his Variations while claiming that they were Paganini's composition. These friends were clearly suspicious that either the rival violinists or their associates had transcribed Ernst's Variations after hearing him perform them at concerts. Accordingly, Ernst sent both violinists personal letters asking if this was true, but received no reply. He then read in a number of newspapers that Sivori was creating a tremendous sensation in Paris, especially with the Carnival, and on $20^{\text {th }}$ April 1843, he wrote a public letter of complaint to the proprietor of the influential Gazette Muiscale. In this letter, Ernst points out that neither Sivori nor 
Hauman had played the Carnival before they heard him perform it, and he asks whether his rival virtuosi believe the piece is by Paganini or himself.

Ernst again received no response, and decided to follow Sivori to England where the Italian was once more spearheading a triumphal tour with the Carnival. Within days of his arrival, Ernst attended one of Sivori's concerts and wrote another public letter, on this occasion to the editor of the Musical Examiner, saying that his suspicions were completely confirmed: not only was Sivori playing the bulk of Ernst's own Variations, but he was even prefacing them with the Andante - unattributed at the concert - which Ernst had published several years before in Paris.

This time, Sivori felt obliged to respond. He claimed that he had received the Andante in manuscript and had no idea it was Ernst's composition, and from this point onwards, he stopped playing it in concerts and substituted an Andante of his own composition. He maintained, however, that he was still entitled to play the Variations, offering a number of obfuscatory and semi-contradictory justifications: they were by Paganini; he only claimed they were a 'souvenir de Paganini'; their style was so indebted to Paganini that only extreme immodesty could lead anyone else to claim ownership; the piece was of such little value that it would be demeaning for anyone - especially two great artists - to argue about who had composed it.

By this stage, the dispute was becoming something of a national scandal, and many British newspapers tore into Sivori's explanations. The Musical World pointed out that earlier in the year Sivori had placed adverts in the Paris musical press saying that he would play the Variations with 'introduction par Ernst' and 'Andante de Ernst'; and other papers, including the influential Morning Post, expressed incredulity at Sivori's explanatory contortions over the Variations themselves. Although Sivori's explanations were accepted in some quarters notably by the influential writer F.J.Fétis and the music critic of the Spectatorthe majority of knowledgeable onlookers felt that Sivori's behaviour was distinctly shifty, and his English reputation took several years to recover. 
Eventually, the two violinists met and reached an accommodation with 'Signor Sivori admitting the undoubted claims of [Ernst] to be the composer [of the Variations]'. But as soon as Ernst left for France in mid-summer, Sivori returned to his old tricks, saying that although the Andante and 'three or four' Variations were by Ernst, the rest were either by Paganini or so close to his manner that it made no difference. Several more public letters were exchanged, and the affair climaxed in two events. First, Ernst published his Variations in late 1843, prefacing them with a note which states his reasons for so doing:

Notice to the public, - when I composed these variations on a theme which had already been varied by Paganini I had no intention of publishing them [as] it was my wish to introduce a piece whose form and character would permit the introduction of that part of the Paganinian difficulties, which, if introduced in a composition of any other kind, would be ill-placed and [indicate] a want of taste and originality. However, the different and inexact arrangements of those which have lately illegally published, as well as the by no means delicate proceedings of certain artists who have played this piece in public without affixing my name, have induced me to consent to its appearance. I declare at the same time, that the present edition of my variations on the Carnival of Venice is the first which has been published with my consent. H.W.Ernst

Second, Heine stated in his account of the 1844 season in Paris, that Ernst's Carnival had been 'pirated in the most shameless manner by Sivori', and yet the Italian took no action for libel against him.

Further useful evidence about Gautier's source of inspiration is supplied by Ernst's wife, Amélie Ernst, whom the violinist married in 1854. Previously known as the young Jewish actress, Amélie-Siona Lévy, she had been positively reviewed by Gautier for a recital in 1848, and over the next four years their relationship developed. The poet used his influence behind the scenes to make sure she acquired the best instruction and rewarding roles, defended her in print against negative reviews, and clearly enjoyed her beauty, charm and company. By 1850, and partly as a result of his support, she had become première tragédienne at the Odéon and begun to write poetry herself. A quatrain by Gautier celebrates her in both roles: 


\section{For Siona Lévy}

Child doubly applauded

You sing and make verse

And your mask of tragedy

Is crowned with green laurels.

At the height of her success, her brother saw a vision of the Virgin, converted to Catholicism, and entered a religious house. Under his influence, she experienced a similar revelation and renounced the stage; it was only meeting Ernst in early 1852 that prevented her entering a nunnery. Once she had met him, however, her life rapidly reverted to its previous course. With her mother acting as chaperone, Amélie and Ernst travelled through the south of France giving recitals of verse and music, and one of their most popular items was for her to read Gautier's recently-published poem, and then for him to play the Variations on which it's based.

After Ernst's death in 1865, she re-established close links with Gautier, whose subsequent reviews helped her new career as poet and public recitalist, and then, in about 1895 she published two books - one of the prose extracts she had used in her public readings for thirty years, and another of the poetry she'd used for the same purpose. The latter, unsurprisingly, contains the text of Gautier's poem, to which is added the following note:

The celebrated variations on the Carnival of Venice are by Ernst, but Sivori, when performing the variations, falsely attributed them to Paganini who never published his own set. Ernst wouldn't have published his either if he hadn't wanted to assert his right to property others had purloined. In the event, he only published twenty-five variations out of more than a hundred he had composed and it's noteworthy that the first edition is preceded by a preface which explains the situation. Théophile Gautier was inspired by the spirit of Ernst's variations which, by mistake, he attributes to Paganini.

Clearly, Madame Ernst has reasons not to be impartial, but this public statement was based on years, not only of constant companionship and performing with Ernst, but also of friendship and discussion with Gautier. As Gautier obviously thought the poem important, and as both the poem and its topic had played such a significant role in Amélie's life, it seems inconceivable they should not have 
discussed the matter at length. It thus seems likely that Amélie's note has Gautier's authority behind it as well as the Ernsts'.

There is also evidence internal to Gautier's poem which points to Ernst's rather than Paganini's piece. Both sets of variations contain many of the musical and violin techniques mentioned in the poem - pizzicato, harmonics, scales, comic effects on the G string etc - but Gautier mentions two devices which are clearly found in Ernst, but much less obviously in Paganini. The first is the 'extravagant' trill:

Colliding with Trivelin, who Extravagantly trills in his handkerchief, Scaramouche returns to Columbine Her fan or her glove.

Here is the most extensive use of trills in Paganini's piece:

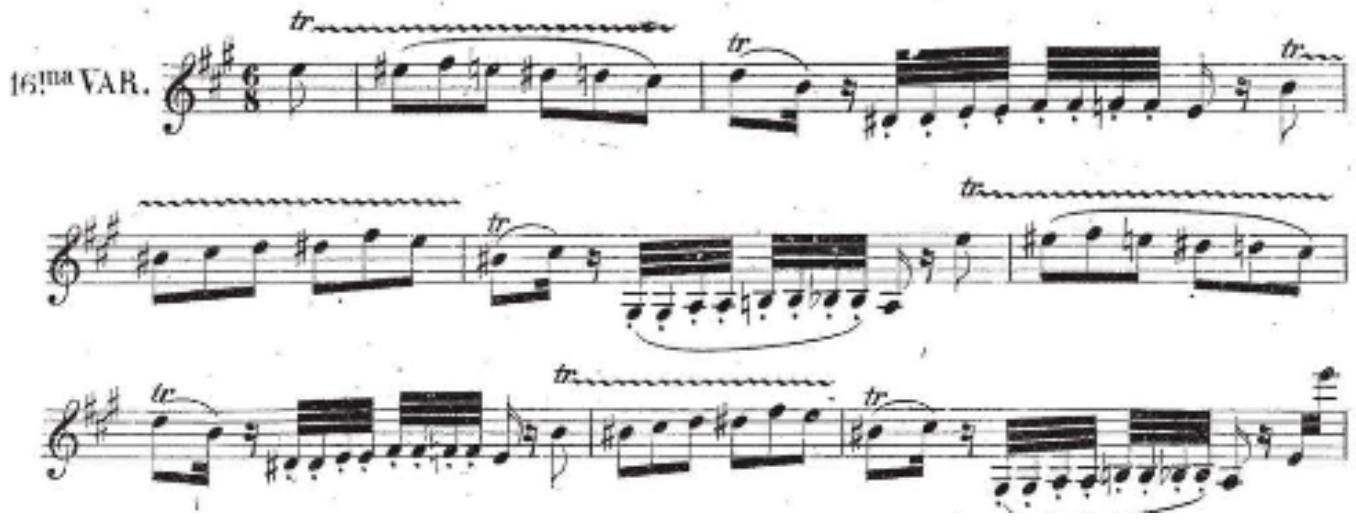

Figure 1: Paganini, Carnival of Venice, Variation 16, bars1-8

Now compare this low-key use of the device, with the way it is used in Ernst's $22^{\text {nd }}$ variation:

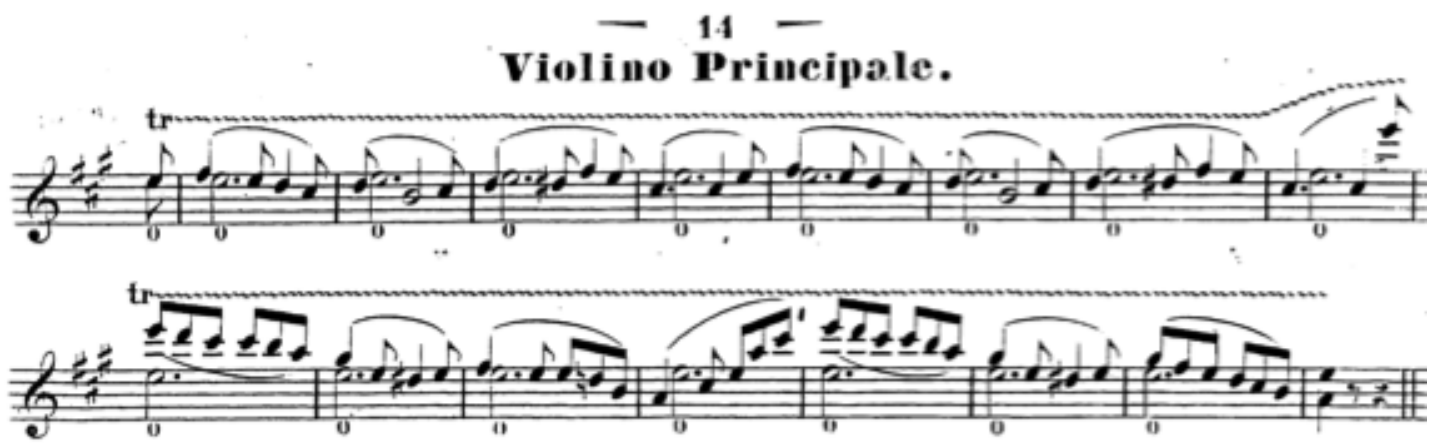


Figure 2: Ernst, Carnival of Venice, 22 ${ }^{\text {nd }}$ Variation, bars 1-16

This is considerably more extravagant: it is the entire first half of a variation, and is more likely to be remembered by a listener. The passage is also much better fitted for conjuring up an image of Scaramouche hesitantly returning a fan or glove to Columbine, while Trivelin trills - i.e. blows his nose - into his handkerchief. I think this is because, in Ernst's passage, a monotonous and obtrusive drone accompanies a melody made slightly bashful and self-conscious - like an awkward suitor - by continuous trilling and unnaturally high positions on the A string.

One other musical feature mentioned by Gautier is a chromatic scale:

At a chromatic scale, Venus of the Adriatic, Her breast swathed in pearls, Rises, pink and white, from the water.

Paganini's Variations contain very few chromatic scales. Their most extensive use is found in the $7^{\text {th }}$ variation:

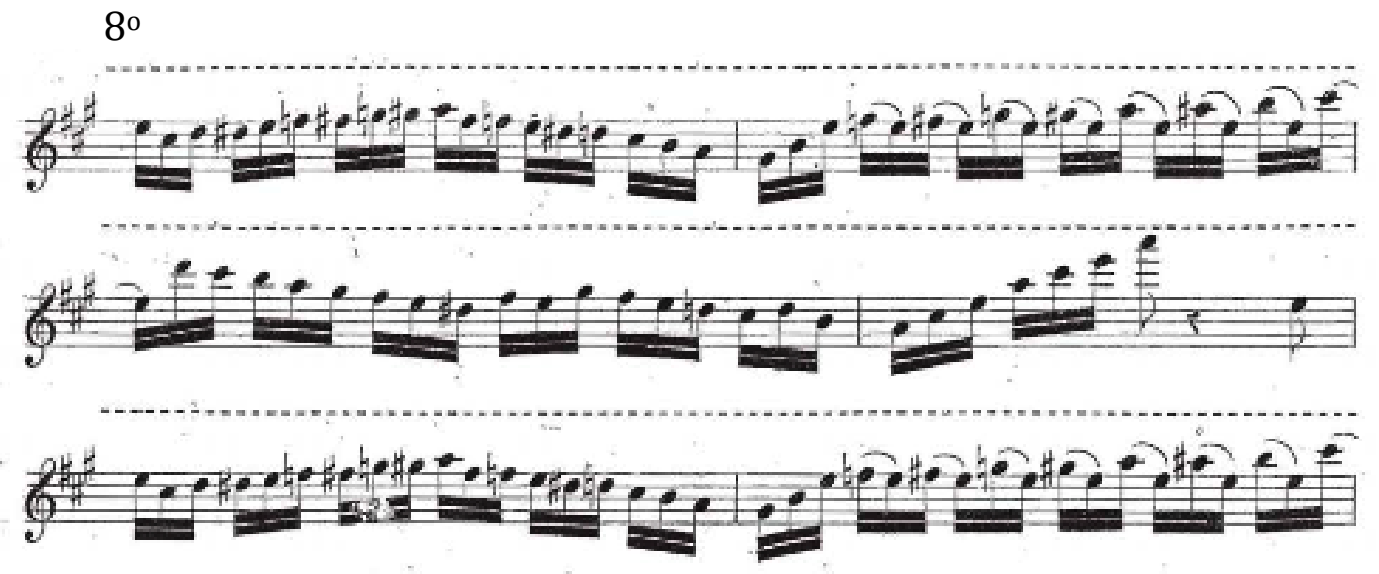

Figure 3: Paganini, Carnival of Venice, Variation 7, bars 9-14

The longer chromatic scales in bars one and five of this extract, echo two similar scales in the first half of the variation, but all of them only involve eight notes each, and are very much passing features which could easily be overlooked. But the same is not true of Ernst's Variations, where wonderfully long chromatic scales make up the entire second half of variation 6: 


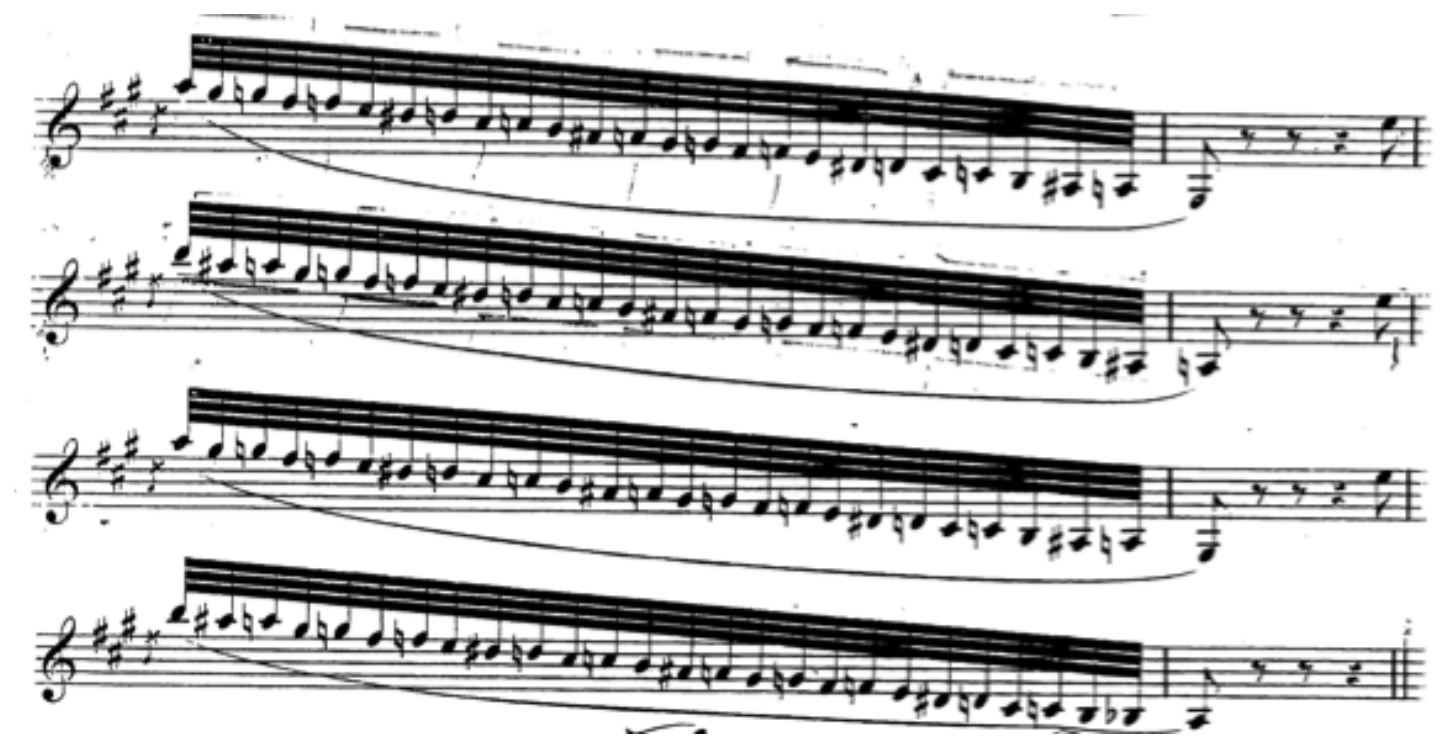

Figure 4: Ernst, Carnival of Venice, Variation 6, bars 9-16

The fact that these are long descending chromatic scales makes them much more suggestive of water pouring from the breast of Venus of the Adriatic as she rises pink and white from the waters, than Paganini's short ascending chromatic scales at the beginning of bars one and five of Figure 3.

The final stimulus for Gautier's poem was a performance of the Carnival of Venice at the Paris Conservatoire by Teresa Milanollo - who had originally made her name as a prodigy playing alongside her sister Maria - in early March 1849. This concert probably came too late to have had a major influence on the poem, but it may have prompted him into making some final revisions and getting the work published.

Whose set of variations Teresa played on this occasion is initially far from clear. Adverts for her concerts around this time, show her advertising Paganini's Adagio Spianato (apparently referring to his Cantabile Spianato) and Carnival of Venice played one after the other, and Gautier obviously thought he had once again listened to Paganini's piece. In a paragraph in his feuilleton on $12^{\text {th }}$ March, Gautier tells his readers that Teresa will perform again that very evening, when she will play 'those charming variations on the Carnival of Venice which no one 
has played better since Paganini and Sivori[,] and obtained a prodigious success at her last concert.'

But there are reasons to be suspicious. The experienced music critic of the Revue et Gazette Musicale, Henri Blanchard - who was a trained composer and violinist, had heard both Ernst and Paganini, and knew all about the Carnival of Venice affair - reviewed the same concert, and hedges his bets (despite the concert posters) as to whom the composer might be:

The exceptional young violinist reprised the whimsical eccentricities of Ernst or Paganini [my italics], known under the title of 'Variations on the Carnival of Venice'. Teresa Milanollo's melancholy figure and serious demeanor stood in marked contrast to the bizarre strangeness of the variations; in fact, she systematically accentuated the comic aspects.

Ernst's name, we notice, is placed before Paganini's, and there are indeed a number of reasons for thinking that Teresa played Ernst's piece. First, Ernst's Variations had been in print for six years, whereas Paganini's Variations would not be published for a further two, and the Cantabile Spianato for another hundred and twenty. Second, Ernst's Variations were hugely popular with audiences, who often laughed out loud, stamped their feet and refused to leave until the piece was played. Consequently, they were in the repertoires of many virtuoso violinists in the late 1840s and 50s, but the same was not true of Paganini's Variations. Third, Ernst's Variations were in Teresa's repertoire, and an advert in a French provincial newspaper in late December 1846 lists 'Carnaval de Venise par Ernst' as the penultimate item on a programme to be given the next day by the Milanollo sisters. I have found no adverts or reviews suggesting they ever played Paganini's Variations. Fourth, Paganini simply entitled his piece Variations whereas Ernst entitled his Variations Burlesques, and Blanchard, in his review, emphasizes how Teresa accentuated their whimsical comedy; in fact, this was one reason they were so popular. Fifth, as Teresa probably knew, there was no danger that Ernst himself would attend her concerts. Until early March 1849, ill health - as well as the continuing political instability from the 1848 Revolution - had confined him to his brother's house in Brünn (modern Brno), after which he headed for Leipzig, Weimar and London. 
Gautier clearly felt that Teresa played the same piece he had heard Sivori play three times in the last six years, and since Sivori played Ernst's Variations, Gautier's feeling was probably entirely accurate. If Gautier heard Paganini play his Variations then this must have been at least fifteen years before (during the violinist's last Parisian concert series in 1834), and it would have required a very accurate musical memory to realize that Sivori was playing a slightly different piece - while claiming to play the same piece - nine or ten years later.

Was Teresa simply following the practice of Sivori and Hauman and lightly disguising the fact that she was playing Ernst's Andante and Variations? Her father, who organized her concerts, was quite happy to acknowledge Ernst as the composer when his Carnival was played in a concert given by two young girls in 1846; indeed, the fact that Teresa had mastered a famously difficult piece by one of the greatest living virtuosi would add to her credit. But Maria Milanollo had died aged sixteen in October 1848, and he was now managing Teresa alone who, at twenty-one, could no longer count as a prodigy.

When she ceased to be a prodigy, Teresa was transformed into Ernst's straightforward rival; in fact, he complains about their rivalry in a letter of December 1853. This change in status would also affect her repertoire. In accordance with the musical mores of the day, Teresa - at least in solo appearances - would be expected to compose most of the pieces she played, and to avoid looking too dependent on works by living competitors. Consequently, Teresa would have exactly the same motivation as Sivori and Hauman for falsely attributing Ernst's composition to a dead and revered master. In fact, as Teresa unlike Sivori and Hauman - already used and acknowledged several works by Ernst in her concert repertoire (including his fantasy on Bellini's Il Pirate) her motivation for mild dishonesty was even stronger.

Ernst's publication of his piece did nothing to end the muddle and subterfuge generated by Sivori and his colleagues. This was largely because Ernst - despite his reasons for publication - did not take sufficient pains to distinguish his 
composition from Paganini's. Perhaps he thought the slightly different title, introductory notice, and larger number of variations were sufficient; perhaps as his preface suggests - he still wanted to think of the piece as a stylistic exercise in Paganinian writing, a tribute to the older man, rather than as an original work in its own right. Whatever his reasons, he miscalculated. He even decided despite the rarity of the indication 'spianato' - to mark the A-major Nocturne (now the Introduction) 'Andante Spianato', in a deliberate echo of Paganini's Cantabile Spianato. As a result, even today, one can find the two pieces regularly confused, not distinguished from one another, and blended together in the most extraordinary way.

But would Teresa have been able to play Paganini's Cantabile and Variations because she had seen manuscript copies? I think the answer is 'no', but for different reasons in each case. She could have approached Paganini's son Achille, who owned Paganini's manuscripts and was, in 1849, readying some of his most important works - including the Carnival - for publication. But as a good deal of the success of this publication depended on nobody's having seen authentic scores of these famous works before, it is most unlikely that he would have allowed Teresa to copy or perform the Variations prior to their release. Achille published Paganini's first two violin concertos, but did not attempt to publish the third - containing the Cantabile - and the most likely reason for this is that either he did not have a manuscript, or, if he did, it was not in publishable condition. When, in the 1960s, Henryk Szeryng put the principal violin part together from a long-untouched heap of moldering manuscripts owned by Paganini's descendants, it took him five days to assemble the first movement alone.

Perhaps she approached, or had been approached by, someone who had transcribed the work from a number of performances by Paganini himself, but there are, once again, strong reasons against this. On the one hand, transcribing one of Paganini's major pieces, involving thousands of rapid notes and very novel virtuoso techniques, was extremely difficult; and this is certainly true of the twenty variations and finale of the Carnival. Consequently, when someone 
succeeded in transcribing a major piece the feat was soon widely known and celebrated - as when Carl Guhr managed to note down the Nel cor Variations in 1829 , or Ernst managed to transcribe the Moses Variations on the G string in 1837 - and then other violinists went on to perform these works, often to great acclaim, at public concerts. But there is no unimpeachable evidence of anyone either transcribing Paganini's Carnival, or of playing it at concerts between 1840 and 1851. On the other hand, the simple, song-like Cantabile Spianato would have been comparatively easy to note down. But again there is no cast-iron reason for thinking that anyone transcribed or played it at a concert. It would be surprising if such an attractive piece remained unperformed between the 1850s and its rediscovery in the late 1960s, if a manuscript transcription existed, and if Teresa Milanollo played it as regularly in the 1840s and 50s as her concert adverts suggest.

So, did Teresa, immediately after the devastating death of her sister, decide to abandon one of her standard showstoppers and learn a new, difficult and much less popular set of variations, bringing this about either by approaching Paganini's son (despite his reasons for being reluctant or unable to help) or some person or persons, unknown to posterity, who had transcribed the Cantabile and Variations (despite the reasons - different in each case - why this would be very difficult to do)? Or did she, or more likely her father, decide to delete the words 'Andante' and 'Ernst' on one of her standard programmes, and substitute the words 'Adagio' and 'Paganini'? Which would be easier? Which had other virtuosi done before? Which would be more probable? I have no hesitation in saying the latter.

Given the testimony and behaviour of Ernst, his friends, and the English newspapers; the published declaration of Madame Ernst; the internal correspondences between certain features of the poem and Ernst's work; and the likelihood of Teresa Milanollo performing Ernst's Variations in early 1849; I think we can be confident that Gautier's poem is a response to Ernst's Carnival and not Paganini's. 
But why did Gautier find himself creatively engaged with Ernst, Sivori and Milanollo rather than Paganini himself? Gautier's imagination tends to seek subject matters that prompt him into reveries and daydreams, and he is characteristically inspired by the sensual, charming and beautiful, rather than the overwhelming, sublime and grotesque. But during a performance by Paganini it was virtually impossible to dream: one was too riveted by the impossible technical novelties being performed, and the spectral, skeletal character performing them. Paganini's presence was too tyrannical, too daemonic, too much of an indigestible singularity, to be able to collaborate creatively with the younger Gautier's imagination.

By the mid-to-late-1830s, however, Paganini's technicalities were being mastered by a group of leading players whose presence was more recognizably human, and his devices were becoming an established part of the violin's expressive repertoire. They were also being taken up by composer-violinists and adapted for their own purposes: their use in Ernst's Variations - more ironic and urbanely humorous, and less likely to provoke awed astonishment than Paganini's - is a case in point. It was when the older Gautier encountered this second generation of performers and composers that his attention could drift away from the stage, and become rapt in the delightful daydreams which gave rise to his poem. Poems inspired by Paganini tend to be about Paganini; this poem - inspired by Ernst, Sivori and Teresa Milanollo - is about Venice. Indeed, the very fact that the three violinists are invisible in the poem, and that their influence can only be discovered by historical research, shows that their music had evoked images vivid enough to occlude their presence.

By 1853, Gautier probably knew he had misidentified the source of his inspiration, and it may seem strange that he did not insert a note to indicate his error in later editions of Émaux et Camées. He may have felt, however, that the mistake had a certain ironic appropriateness and should remain untouched: after all, Venice is the city of disguises, illusions, reflections, and appearances. 
